\title{
Balancing Ukraine's energy system: challenges under high renewable energy penetration and the COVID-19 pandemic
}

\author{
Tetiana Kurbatova ${ }^{1, *}$, Iryna Sotnyk ${ }^{2}$, Olha Prokopenko ${ }^{3}$, Roman Sidortsov ${ }^{4}$, and Yu-xia $\mathrm{Tu}^{5}$ \\ ${ }^{1}$ Sumy State University, International Economic Relations Department, 2 Rimsky-Korsakov Str., Sumy, 40000, Ukraine \\ ${ }^{2}$ Sumy State University, Department of Economics, Entrepreneurship and Business Administration, 2 Rimsky-Korsakov Str., Sumy, 40000, \\ Ukraine \\ ${ }^{3}$ International Humanitarian University, Economics and International Economic Relations Department, 33 Fountain Road Str., Odessa, \\ 65000, Ukraine \\ ${ }^{4}$ Michigan Technological University, Department of Social Sciences, 1400 Townsend Drive, Houghton, MI 49931, United States \\ ${ }^{5} \mathrm{Xi}$ 'an Peihua University, School of Accounting and Finance, 888 Changing str., Shaanxi, China
}

\begin{abstract}
The paper deals with the problems of balancing the United Energy System of Ukraine caused by high renewable energy penetration and the impact of the COVID-19 pandemic on the energy sector. The paper analyses the trends in renewable energy development, the dynamics and structure of electricity consumption and export in pre-epidemic and epidemic periods and identifies the main challenges to operational security of the United Energy System of Ukraine. The methodical approach to improve the methodology for estimation of country's energy security level by considering the index of developing capacities for balancing the United Energy System of Ukraine is suggested. In addition, proposals have been made to reduce threats to the stable work of the United Energy System of Ukraine by putting into operation of energy storage capacities, promoting the development of maneuvering renewable energy capacities, and implementation of other appropriate measures in this field.
\end{abstract}

\section{Introduction}

One of the important indicators that affects the energy security of any country is the stable operation of the energy system. The peculiarity of the United Energy System of Ukraine is deficit of maneuvering energy capacities, as nuclear power plants cover about 50\% of electricity demand in the country [1]. In recent years, this problem has been enhanced by putting into operation of renewable power plants, especially solar and wind ones, electricity generation based on which is unstable, as it is directly dependent on the season, time of day and weather conditions.

This issue has developed into the energy crisis in 2020. During the quarantine restrictions caused by the COVID-19 pandemic, the rapid growth of green electricity generation was compounded by the problem of declining domestic demand for electricity and limiting opportunities for its export [2]. This, in turn, has caused technical difficulties with integrating renewable electricity into the United Energy System of Ukraine and its balancing.

The purpose of this paper is to: 1) study of the main challenges for the operational security of the United Energy System of Ukraine caused by high renewable energy penetration and the impact of the COVID-19 pandemic on the country's energy sector; 2) improve the methodology for assessing the energy security of Ukraine by taking into account the level of development of capacities for balancing the United Energy System of Ukraine; 3) develop the recommendations on effective balancing the United Energy System of Ukraine taking into account the priorities for the transition to a carbonfree economy.

\section{Features of Ukraine's United Energy System operation}

The United Energy System of Ukraine is a set of power plants operating on conventional and renewable energy resources, main and distribution networks, which are united by a common way of production, transmission, and distribution of electricity [1].

The mode of the United Energy System of Ukraine is determined based on the balance of generation and consumption of electricity, repairs of power grids and generating equipment, as well as the possibility of emergency response in case of disconnection of generating equipment at power plants and main power lines. The balance between generation and consumption of electricity provided through the process of scheduling. The main dispatcher of the United Energy System of Ukraine is the National Power Company "Ukrenergo", which takes the necessary measures to prevent violations of its mode of operation.

Peaks in electricity consumption occur during the day and evening. Maneuvering capacities of thermal power

\footnotetext{
* Corresponding author: t.kurbatova@macro.sumdu.edu.ua
} 
plants, hydropower plants, including pump storage power plants, are used for regulation and passage of peak loads.

Part of the capacities of hydropower plants is in the "hot reserve" - on idle, but heated steam generators and turbines are maintained nominal operating parameters, so they can be started in minutes. Today, the capacity of the "hot reserve" in the electricity generation of Ukraine is about 300-400 MW [1].

The balance between maneuvering generating capacities and power plants that cannot maneuver quickly is one of the conditions for the stable functioning the United Energy System of Ukraine.

\section{Challenges to the United Energy System of Ukraine caused by high renewable energy penetration and the COVID-19 pandemic}

In recent years, the balance between maneuvering and non-maneuvering generating capacities in the United Energy System of Ukraine has been disturbed due to the dynamic putting into operation of renewable power plants, especially solar and wind ones, the generation of electricity based on which is difficult to predict (Table 1).

Table 1. Number and structure of renewable power plants put into operation in Ukraine in 2017-2019 [3, 4, 5].

\begin{tabular}{|l|c|c|c|}
\hline Renewable power plants & $\mathbf{2 0 1 7}$ & $\mathbf{2 0 1 8}$ & $\mathbf{2 0 1 9}$ \\
\hline $\begin{array}{l}\text { Solar power plants } \\
\text { including solar power } \\
\text { plants of private } \\
\text { households }\end{array}$ & 3203 & 7806 & 22548 \\
\hline Wind power plants & 2010 & 7450 & 21969 \\
\hline Biomass power plants & 27 & 43 & 69 \\
\hline Small hydropower plants & 137 & 149 & 157 \\
\hline Total & 3387 & 8029 & 23111 \\
\hline
\end{tabular}

As shown in Table 1, the number of renewable power plants in 2019 increased 6.8 times compared to 2017. The largest growth was shown by solar power plants, both in the business sector and the private households. The increase in the number of renewable power plants, therefore, contributed to the increase in the amount of electricity generated on their basis (Table 2).

Table 2. Dynamics and structure of electricity generation by renewable power plants in Ukraine in 2017-2019, million kWh $[3,4,5]$.

\begin{tabular}{|l|c|c|c|}
\hline Renewable power plants & $\mathbf{2 0 1 7}$ & $\mathbf{2 0 1 8}$ & $\mathbf{2 0 1 9}$ \\
\hline $\begin{array}{l}\text { Solar power plants } \\
\text { including solar power } \\
\text { plants of private } \\
\text { households }\end{array}$ & 737.4 & 1172 & 3235 \\
\hline Wind power plants & 22.7 & 92 & 303 \\
\hline Biomass power plants & 1943.5 & 1180.2 & 2022 \\
\hline Small hydropower plants & 212.5 & 245.4 & 309 \\
\hline Total & 2118.2 & 2869.2 & 5808 \\
\hline
\end{tabular}

According to Table 2, it can be concluded that the amount of electricity generated by renewable power plants in 2019 increased 2.7 times compared to 2017 and 2 times compared to 2018 .

The predominance in the structure of generation of solar and wind energy is due to the maturity of these technologies. Global experience shows that most investors prefer to invest in these technologies. Thus, in 2018 , solar energy accounted for $48.9 \%$, wind energy $47.2 \%$ of total new investments [6]. However, other countries, along with promoting these technologies development, pay considerable attention to the effective integration of such electricity into the national energy systems, but in Ukraine such measures have not been taken.

In 2020, this problem was exacerbated by the impact of quarantine restrictions caused by the COVID-19 pandemic, which contributed to significant reduction in domestic demand for electricity (Table 3 ).

Table 3. Dynamics and structure of electricity consumption in Ukraine for 9 months of 2017-2020, million kWh [7].

\begin{tabular}{|l|c|c|c|}
\hline \multicolumn{1}{|c|}{ Consumer groups } & $\begin{array}{c}\mathbf{9} \text { months } \\
\mathbf{2 0 1 8}\end{array}$ & $\begin{array}{c}\mathbf{9} \text { months } \\
\mathbf{2 0 1 9}\end{array}$ & $\begin{array}{c}\mathbf{9} \text { months } \\
\mathbf{2 0 2 0}\end{array}$ \\
\hline Total & 89659.8 & 89553.9 & 86238.6 \\
\hline including: & 38655.3 & 38550.9 & 36493.5 \\
\hline 1. Industry & 2623.8 & 2533.4 & 2378.9 \\
\hline including: & 22117.2 & 22063.4 & 20366.7 \\
\hline Energy sector & 2395.4 & 2702.2 & 3099.9 \\
\hline $\begin{array}{l}\text { Metallurgical sector } \\
\text { petrochical and }\end{array}$ & 2972.0 & 2734.2 & 2256.6 \\
\hline Machine-building sector & 1681.1 & 1668.5 & 1676.9 \\
\hline $\begin{array}{l}\text { Building materials sector } \\
\text { Food and processing } \\
\text { sector }\end{array}$ & 3259.9 & 3294.6 & 3152.0 \\
\hline Other sectors & 3606.0 & 3554.6 & 3562.4 \\
\hline 2. Agricultural sector & 2864.9 & 2778.0 & 2798.4 \\
\hline 3. Transport sector & 5090.7 & 4856.4 & 4117.0 \\
\hline 4. Construction & 691.1 & 711.1 & 669.9 \\
\hline $\begin{array}{l}\text { 5. Utility consumers } \\
\text { sector }\end{array}$ & 11357.5 & 11276.5 & 10289.1 \\
\hline $\begin{array}{l}\text { 6. Other non-industrial } \\
\text { consumers }\end{array}$ & 4975.3 & 5444.4 & 5264.6 \\
\hline 7. Population & 26024.9 & 25936.6 & 26606.1 \\
\hline
\end{tabular}

As shown in Table 2, electricity supply to final consumers for 9 months of 2020 decreased by 3315.3 million $\mathrm{kWh}$ compared with 9 months of 2019. The decrease in consumption was observed in almost all consumer groups. The exception were the chemical and petrochemical sector, agricultural sector, and households. Adding to the above problems it was the reduction in electricity exports, as quarantine measures caused by the COVID-19 pandemic led to the reduction in electricity demand in importing countries, namely Hungary, Romania, Poland, and Belarus (Figure 1).

As can be seen from Fig. 1, starting from March 2020, the period of implementation of the lockdown due to the COVID-19 pandemic, electricity export declined sharply, and only in July began to show growth with positive dynamics. However, in September it was still 1.6 times less than in March 2020 [5].

The above trends have caused the problem of effective balancing the United Energy Systems of Ukraine, 
violating the equality of electricity supply and demand. To solve this problem, the government has decided to shut down several power units of nuclear power plants in the country [8]. This choice was caused the fact that nuclear power plants cannot maneuver their capacity, and the dynamic growth of renewable energy requires the flexibility of the energy system. The decision to limit the green electricity generation was not made because according to Ukrainian law, the state has obligations to: 1) purchase the total amount of green electricity by feedin tariff until 2030 [9]; 2) increase the share of green electricity in the total energy mix, in the framework Ukraine's membership in the European Energy Community; 3) achieve strategic goals for renewable energy development, specified in the Energy Strategy of Ukraine until 2035 [10].

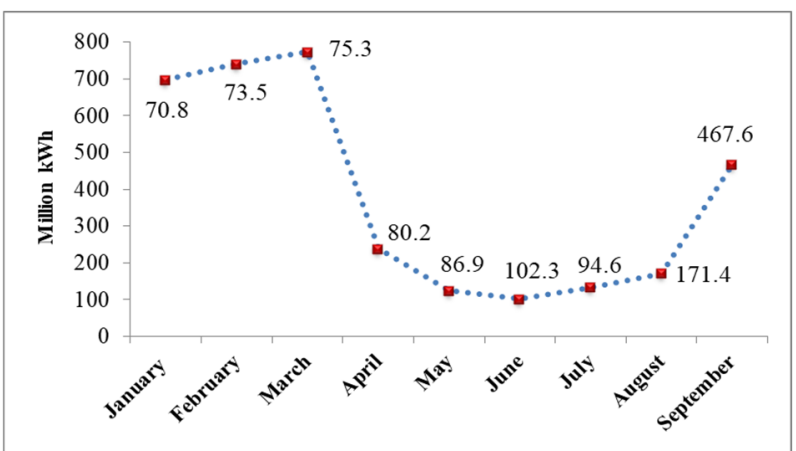

Fig. 1. Dynamics of electricity exports for 9 months of 2020, million kWh [11].

It should be noted that nuclear power plants generate the cheapest electricity in country (580 UAH / MWh), while electricity from renewable energy sources is purchased at the feed in tariff that is one of the highest in Europe (the average feed-in tariff for all renewable energy technologies represented on the Ukrainian market is 4705 $\mathrm{UAH} / \mathrm{MWh}$ ) [12]. It has led to a significant increase in the weighted average unit cost of electricity and, as result, to increasing in electricity prices for households and industry. To partially reduce the effects of rising electricity prices, the government has decided to reduce the feed-in tariff by $7.5 \%$ for wind farms and $15 \%$ for solar power plants. It is predicted that it will provide savings of about 6 bln UAH each year until the end of the period to support scheme for renewable energy promotion based on feed-in tariff in 2030 [13]; however, at the same time, it will worsen the investment climate in the renewable energy sector.

\section{Improving the methodology for assessing the energy security of Ukraine}

Unstable functioning the United Energy System of Ukraine is a direct threat to both energy and economic security of the country, so the indicator of development of capacities for balancing the energy system should be included in the calculation of the integrated indicator of energy security.

Today, the level of energy security of Ukraine is determined based on the Guidelines for calculating the level of economic security of Ukraine, approved by the order of the Ministry of Economic Development and Trade of Ukraine No 1277, 29.10.2013 [14]. According to [14] the integrated indicator of energy security is calculated based on 10 indicators, namely:

- the share of own sources in the balance of fuel and energy resources of the state, \%;

- the level of import dependence on the dominant resource in the total supply of primary energy, $\%$;

- the share of fuel import from one country (company) in the total amount of its import, $\%$;

- depreciation of fixed assets of the fuel and energy complex, \%;

- the ratio of investment in the fuel and energy sector to gross domestic product, $\%$;

- energy intensity of gross domestic product, $\mathrm{kg}$ of fuel equivalent / UAH;

- natural gas reserves, months of consumption;

- coal reserves, months of consumption;

- the share of renewable energy resources in the total supply of primary energy, $\%$;

- the share of losses in the transportation and distribution of energy, $\%$.

It is worth noting that the capacities for balancing the United Energy System of Ukraine include Maneuvering power plants and energy storage systems.

Thus, the indicator of development of capacities for balancing the United Energy System of Ukraine can be calculated by the formula:

$$
I_{b}=\frac{\sum M P_{i}+E S}{\sum P P_{i}}
$$

where $I_{b}$ - index of development of capacities for balancing the United Energy System of Ukraine; $M P_{i}-$ installed capacity of the $i$-type of maneuvering power plants, $E S$ - installed capacity of the $i$-type of energy storage systems, MW; $E P_{i}$ - installed capacity of the $i$ type of power plants in the United Energy System of Ukraine, MW.

The optimal value of the above index is reached at values close to unity. In this case, the maximum level of development of energy capacities for balancing the United Energy System of Ukraine is provided, which has a positive effect on increasing the level of energy security of the country.

It should be noted that at present balancing the United Energy System of Ukraine is carried out by thermal power plants and hydropower plants (including pump storage power plants). For this purpose, it also can be used combined heat and power plants and biopower plants. At the same time nuclear, solar, and wind power plants are not flexible and can be used for balancing energy system. The dynamics of the installed capacity of power plants in the United Energy System of Ukraine in 2017 - 9 months of 2020 are shown in Table 4.

The data presented in Table 4 show significant increase in the installed capacity of solar and wind power plants that worsens the balance between flexible and nonflexible power plants and threatens the stable functioning the United Energy System of Ukraine. These risks can be 
reduced by implementing several measures, which are discussed in more detail in the next section.

Table 4. Installed capacity of power plants in the United Energy System of Ukraine in 2017 - 9 months of 2020, MW $[15,16,17,18]$.

\begin{tabular}{|c|c|c|c|c|}
\hline \multirow[b]{2}{*}{$\begin{array}{l}\text { Power plants in the United } \\
\text { Energy System of Ukraine }\end{array}$} & \multicolumn{4}{|c|}{ Installed capacity, MW } \\
\hline & 2017 & 2018 & 2019 & $\begin{array}{c}9 \\
\text { months } \\
2020\end{array}$ \\
\hline Thermal power plants & 24565 & 21842 & 21842 & 21842 \\
\hline $\begin{array}{l}\text { Combined heat and power } \\
\text { plants }\end{array}$ & 5972.3 & 6099.5 & 6097 & 6070 \\
\hline $\begin{array}{l}\text { Hydropower plants (including } \\
\text { pump storage power plants) }\end{array}$ & 6228.7 & 6170.2 & 6520 & 6300 \\
\hline Biopower plants & 96.9 & 97.5 & 170 & 177 \\
\hline Nuclear power plants & 13835 & 13835 & 13835 & 13835 \\
\hline Solar power plants & 758.4 & 1388.3 & 4925 & 4938 \\
\hline Wind power plants & 328.4 & 532.8 & 1170 & 1071 \\
\hline
\end{tabular}

\section{Measures for effective balancing the United Energy System of Ukraine}

A few measures can be used for effective balancing the United Energy System of Ukraine, namely: introduction of additional flexible capacities of conventional power plants, promotion of development of flexible renewable power plants, installation of energy storage systems, import of electricity from other countries, introduction of more accurate forecasting methods, responsibility for imbalance, electricity demand management, etc. [19].

Balancing energy system by existing fossil fuels power plants and construction of new ones is the least appropriate in terms of considering the priorities for the transition to a carbon-free economy.

In should be noted that currently Ukraine holds the leading position in the world for energy intensity of gross domestic product and it is included to 30 world countries, which are the largest polluters with $\mathrm{CO}_{2}$ emissions due to burning fossil fuels [20]. It is an energy sector takes the first place for $\mathrm{CO}_{2}$ emissions among other sectors of national economy in Ukraine: its share was about $76 \%$ of total $\mathrm{CO}_{2}$ emissions during the last years.

Besides, Ukraine has a commitment to reduce greenhouse gas emissions by $40 \%$ from 1990 level by 2030 and by $70 \%$ by 2050 under the Paris Climate Agreement (Figure 2) [21].

The construction of new power plants based on fossil fuels for this purpose is impractical not only from environmental point of view, but also from economic one. Thus, the costs of electricity generation by solar photovoltaic plants and onshore wind plants decreased by $82 \%$ and $39 \%$, respectively, compared to 2010 . More than half of the renewable power plants put into operation in 2019 achieved lower electricity generation costs than fossil fuel power plants [22].

Partly improve the situation with balancing the United Energy Systems of Ukraine it is possibly by regulation of construction of new renewable power plants under the new support scheme for renewable energy promotion the green auctions.

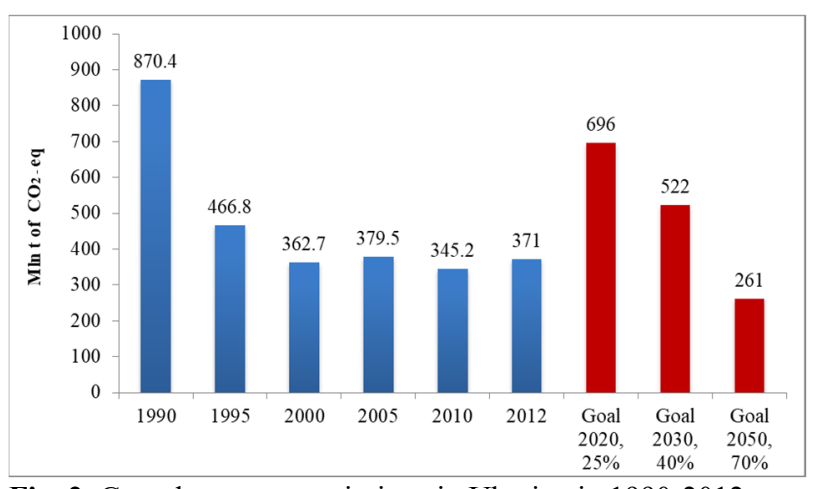

Fig. 2. Greenhouse gas emissions in Ukraine in 1990-2012 (million tonnes of $\mathrm{CO}_{2}$ eq) and targets for 2020-2050 (\%) [22].

This mechanism is designed to identify renewable power projects that will receive state support for electricity generation. Green auctions based on following: the winner is the investor who offers the lowest price for green electricity. The starting price of bidding is the rate of the feed-in tariff established by the Ukrainian legislation. The winner gets the opportunity to build new renewable power plant and sell electricity at a price determined at the auction for 20 years from the date of commissioning of the power plants [23].

Under this mechanism, the government sets annual support quotas for the next five years. The size of quotas determines how many new renewable power capacities the state is ready to support. Quotas will be calculated in accordance with Ukraine's international obligations, Energy strategy of Ukraine, conformity assessment of generating capacities, etc.

The total support quota is divided into three lots solar, wind and other renewable energy sources. Competition at green auctions takes place between projects in one category. The share of quotas for each category cannot be less than $15 \%$. It should be noted that the legislation also provides for the possibility of conduction of technology-neutral auctions [25].

Green auctions are a market mechanism; this is its main advantage over the feed-in tariff. Competition allows to determine a fair price for green electricity, that will be more beneficial for the state and final consumers.

The start of green auctions, which would legally limit the number of renewable power plants, was planned in 2020 , but was postponed due to the lack of annual quotas determining the total capacity of renewable energy projects that claims the feed-in tariff [24].

It should be noted that within the framework of this mechanism it is reasonable to introduce additional incentives aimed at promoting the development of hydropower and biopower plants. In addition to the advantages associated with the stability of electricity generation based on them, the ability to maneuver capacity, the electricity generation cost based on such power plants is much lower compared to solar and wind ones that, in turn, will put less pressure on the final consumers.

Financial liability for electricity imbalances, when producers and consumers pay for an inaccurate forecast, can partially improve the situation with balancing the energy system. Although its introduction does not increase the flexibility of the energy system, it encourages 
market participants to build balancing capacities or use more accurate systems to forecast electricity generation.

This approach is already provided for by the amendments to the Law of Ukraine "On the Electricity Market" [25]. Thus, according to [25] producers are obliged to bear financial responsibility for the imbalance of electricity, in case of non-compliance with the hourly schedules of its transmission. For producers of electricity from renewable energy resources, this legislative norm will take effect from January 1, 2021 - for power plants put into operation after April 2017, which are part of the balancing group of producers at the feed-in tariff. It is $10 \%$ of the cost of settling the imbalance and will grow by $10 \%$ annually.

Another requirement regarding reimbursing the cost of the imbalance to 31 December 2029 is the occurrence of conditions when the deviation of the actual hourly electricity supply from the hourly schedule exceeds $20 \%$ for wind farms, $5 \%$ - for small hydropower plants, and $10 \%$ - for solar power plants [26].

The most promising option for balancing the energy system in the conditions of rapid development of renewable energy and instability of electricity demand is the development of energy storage facilities.

Energy storage systems have several advantages because they allow [27]:

- to regulate the generation and consumption of electricity, accumulating its surplus in the least necessary time for consumers and giving it to the network when demand exceeds supply;

- to avoid financial responsibility for imbalances in case of non-fulfillment of hourly schedules of electricity transmission;

- increase the security of electricity supply in case of emergencies. when the electricity generation at power plants is impossible. In such cases, energy storage systems will be able to provide an uninterrupted supply of electricity for a certain period.

To date, no energy storage system has been installed in Ukraine. The first projects to build a network of energy storage facilities with capacity of $220 \mathrm{MW}$ are planned to be implemented by the National Power Company "Ukrenergo" together with the European Bank for Reconstruction and Development and the International Finance Corporation within the framework of the signed memorandum in 2019 [28]. However, large-scale implementation of energy storage systems requires the formation of a legal framework and the introduction of motivational mechanisms under new or existing schemes supporting the renewable energy development.

\section{References}

1. VS Energy International Ukraine LLC. Operating mode of the United Energy System of Ukraine (2020) https://cutt.ly/2jrkfmA. Accessed 24 Dec 2020

2. KRMG. Coronavirus vs energy: why green auctions don to work (2020) http://surl.li/ipzj. Accessed 24 Dec 2020
It should be noted that above measures should be considered in conjunction with other ones that may have a positive impact on the effective integration of green electricity into the United Energy System of Ukraine. Such measures include: connection of Ukraine's energy system to the grid of the European Union with a permit to import electricity [29]; introduction of demand management mechanisms, when consumers are actively involved in balancing the grid, for example, charging electric cars in moments of excess electricity [29]; development of decentralized energy systems based on renewable energy resources $[30,31]$, as a large number of geographically spaced renewable power plants will reduce the unevenness of the electricity production schedule and increase the flexibility of the grid.

\section{Conclusions}

The COVID-19 pandemic has become a global determinant that has had a significant negative impact on Ukraine's energy market. One of the consequences of the quarantine restrictions caused by the COVID-19 pandemic for the Ukrainian energy market was a decrease in domestic demand for electricity and a reduction in electricity export. Against the background of the growing share of green electricity in final energy consumption, these problems have escalated into an energy crisis and created challenges to the operational security of the United Energy System of Ukraine. This leads a revision of the state policy on the renewable energy development, implementation of appropriate measures to increase the flexibility of the energy system and on their basis improving the current methodology for calculating the country's energy security. The main such measures include the development of maneuvering energy capacities and electricity storage systems. These measures can be strengthened by the implementation of a number of secondary measures, which are described in this paper.

The research has been supported by the National Research Foundation of Ukraine under the projects "Formation of economic mechanisms for sustainable development of renewable energy in the conditions of global and local threats to energy security of Ukraine" (No. 2020.01/0135) and "Stochastic modelling of road map for harmonizing national and European standards for energy market regulation in the transition to a circular and carbon-free economy" (No. 2020.02/0231).

3. State Agency on Energy Efficiency and Energy Saving of Ukraine. Information on capacity and amount of electricity production by renewable electricity plants of 31.12.2017 (2017) http://surl.li/itcq. Accessed 25 Dec 2020

4. State Agency on Energy Efficiency and Energy Saving of Ukraine. Information on capacity and amount of electricity production by renewable electricity plants of 01.01.2019 (2019) 
https://saee.gov.ua/sites/default/files/4_2018.pdf. Accessed 26 Dec 2020

5. State Agency on Energy Efficiency and Energy Saving of Ukraine. Information on capacity and amount of electricity production by renewable electricity plants of 01.01.2020 (2020) https://saee.gov.ua/sites/default/files/VDE_2019.pdf . Accessed 24 Dec 2020

6. T. Kurbatova, T. Perederii, Global trends in renewable energy development, in IEEE KhPI Week on Advanced Technology, October 5 - 10, 2020, Kharkiv, 260-263. doi:10.1109/KhPIWeek51551

7. Ministry of Energy of Ukraine. Information on the operation of the power sector in 2017-2020 (2020). http://surl.li/itcd. Accessed 24 Dec 2020.

8. UA.News, 2020. Energy crisis: why nuclear power units are shut down in Ukraine (2020). https://tinyurl.com/yd99vhyg. Accessed 25 Dec 2020

9. Verkhovna Rada of Ukraine. Law of Ukraine "On Electric market”, No 27-28 (2017) http://surl.li/gpcz. Accessed 22 Dec 2020

10. Energy Strategy of Ukraine for the period up to 2035 , 18.09.2017 No 605-p. (2017) http://surl.li/gkfz. Accessed 24 Dec 2020

11. Ukrinform. Ukraine has increased electricity exports by 2.7 times (2020). http://surl.li/ipys. Accessed 24 Dec 2020

12. SE "Energy market". Price analysis in the Wholesale Electricity Market (2019) http://www.er.gov.ua/doc. $\mathrm{php} ? \mathrm{c}=5$. Accessed 20 Dec 2020

13. Government portal. The President signed a law on improving the conditions for supporting green energy: major changes Sources" (2020). http://surl.li/ipyw. Accessed 24 Dec 2020

14. Ministry of economic development and trade of Ukraine. Guidelines on the calculation of the level of economic security of Ukraine 29.10.2013 № 1277 (2013) http://surl.li/itcj. Accessed 24 Dec 2020

15. NCSREPU. Report on the results National Commission for State Regulation of Energy and Public Utilities activity in $2017 \quad$ (2018) http://surl.li/itba. Accessed 24 Dec 2020

16. NCSREPU. Report on the results National Commission for State Regulation of Energy and Public Utilities activity in 2018 (2019) http://surl.li/itbg. Accessed 24 Dec 2020

17. NCSREPU. Report on the results National Commission for State Regulation of Energy and Public Utilities activity in 2019 (2020) https://cutt.ly/Sjrl7pX. Accessed 24 Dec 2020
18. NPC "Ukrenergo". The installed capacity of the power system of Ukraine as of 9 months of 2020 (2020) https://cutt.ly/wjrl8Lk. Accessed 26 Dec 2020

19. Mind. Energy balance: what is needed to create balancing capacities in Ukraine (2019) https://cutt.ly/Vjrkx4N. Accessed 24 Dec 2020

20. Netherlands Environmental Assessment Agency. Trends in global $\mathrm{CO}_{2}$ and total greenhouse gas emissions: $2019 \quad$ Report (2020) https://cutt.ly/xjrkExm. Accessed 25 Dec 2020

21. Economic truth. The Paris Climate Agreement: Challenges for Ukraine (2016) https://cutt.ly/8jr19rD. Accessed 25 Dec 2020

22. IRENA. Renewable power generation costs in 2019 (2020) https://cutt.ly/OjrknDB. Accessed 24 Dec 2020

23. Hmarochos. Auctions have replaced the feed-in tariff for power plants. What does it mean? (2020). http://surl.li/ipzg. Accessed 24 Dec 2020

24. League business. The launch of green auctions has been postponed (2020) http://surl.li/itaw. Accessed 24 Dec 2020

25. Law of Ukraine “On the Electricity Market”, № 2728

(2017)

https://zakon.rada.gov.ua/laws/show/2019-19. Accessed 24 Dec 2020

26. D. Chumak, D. Zmievets, How to ensure stable operation of the power system of Ukraine (2019). https://cutt.ly/ZzPfre5. Accessed 24 Dec 2020

27. V. Kulinich, J. Cheker, Renewable energy: are there prospects for investment (2019). http://surl.li/jjla. Accessed 24 Dec 2020

28. NPC "Ukrenergo". The EBRD and IFC will start implementing projects to develop an energy storage system in Ukraine (2019) http://surl.li/ipzi. Accessed 24 Dec 2020

29. Heinrich-Böll-Stiftung. Green-coal paradox: cannot stop, where is the coma? (2020) http://surl.li/itca. Accessed 25 Dec 2020

30. T. Kurbatova, Ye. Hyrchenko, Energy co-ops as a driver for bio-energy sector growth in Ukraine, in IEEE 3rd International Conference on Intelligent Energy and Power Systems, Kharkiv, September 1014, (2018) https://doi.org/10.1109/IEPS. 2018.8559516

31. T. Kurbatova, T. Skibina, Renewable energy policy in Ukraine's household sector: measures, outcomes and challenges, in IEEE International Conference on Modern Electrical and Energy Systems, Kremenchuk, September $23-25$, (2019) https://doi.org/10.1109/MEES.2019. 8896399. 